\title{
MAGI2 Gene Mutation
}

National Cancer Institute

\section{Source}

National Cancer Institute. MAGI2 Gene Mutation. NCI Thesaurus. Code C150683.

A change in the nucleotide sequence of the MAGI2 gene. 